\title{
Unemployment and Economic Development In Nigeria (1980-2017)
}

\author{
Davis 0jima \\ Ignatius Ajuru University Of Education, \\ Rivers State, Nigeria
}

\begin{abstract}
Unemployment is a global phenomenon which has attracted the attention of developed and developing nations because of its attendant consequences. Given the incidence of unemployment in the country and its attendant consequences this study investigates the empirical relationship between unemployment and economic development in Nigeria. Using the ordinary least technique and time series data from 1980-2017, the study explored the relationship between unemployment and economic development in Nigeria. The result shows that unemployment has negative effect on economic development of Nigeria. This implies that an inverse relationship exist between unemployment and economic development in Nigeria. In the light of the findings, the study recommended that the government should create employment opportunities in order to reduce drastically our unemployment rate, fiscal policy and monetary policy that can induce job creation should be adopted. Skill acquisition and on the job training programmes should be highly encouraged so as to achieve sustainable economic growth and development in Nigeria.
\end{abstract}

Keywords: Unemployment, Economic Development.

\section{INTRODUCTION}

The issue of unemployment has become a global phenomenon demanding increased attention, but the impact is more devastating in developing nation (Wamukonya, 2003). According to the National Bureau of Statistics (2017), Nigeria rate of unemployment stand at $69.7 \%$. In fact, Feridum and Akindele (2006); George and Oseni (2012); Ezie (2012) and Ede, Ndubisi, and Nwankwo (2013), identifies unemployment as one of the major hydra headed problem confronting the Nigeria-economic development. The menace of unemployment in Nigeria both now and in the recent past has been an issue of great concern to the economists, policy makers, economic managers, individuals, government and many others (Bello, 2003). Earlier thinkers on economic issues pointed out the undesirability of unemployment and its attendance consequences (Njoku and Ihugba, 2011).

Akpakpan (1999), noted that, when we discuss the problem of unemployment, generally, we focus on labour. This is because in general, it is the unemployment of labour that is most easily noticed. But it should be noted that the unemployment of the other factors of production also affects the economy and society. We generally associate unemployment in the economy with business cycles.

The economic consequences of unemployment are clearly explained in the words of Akpakpan (1999) thus:

When the economy does not generate enough jobs to employ all those who are willing to work, valuable resources is lost. Potential goods and services that might have been enjoyed by consumers are lost forever. This is the real economic cost of unemployment and no insurance plan can eliminate it. 
This is why economists often say that unemployment is a colossal waste of resources and should be avoided. Unemployment devalues or debases the standard of quality of life in the society (Adams, 1995). He reiterated that the working force would not be able to get another and as a result of these, the number of frustrated and alienated workers has increased.

Generally, unemployed feel left out by the society, this feeling of being left out by the society often drive some unemployed persons into deviant acts. Such acts impose severe costs on the society which include losses due to the diversion of resources from productive activities into preventing or fighting deviant acts, and losses due to general feeling of insecurity that usually characterizes life in such a society. This shows that some of the deviant behavior experience in societies today is predicated on economic and social conditions. The economic and social costs of unemployment made it one of the most worrying problems of nations as we stated earlier. This is why, as you may have noticed, that combating unemployment occupies centre stage in government programme and policies.

However, there are many studies on unemployment and its negative impact on economic growth and development. Most of these studies (Totunbo, 2006 , Moses and Anuforo, 2011) concentrated on its effect on economic growth proxy by real gross domestic product (RGDP). The few scholars (Anayochukwu, 2014 and Peters,2016) that examined its effect on economic development proxies economic development with per capita income and some of them are state centred. However this paper uses human development index a more encompassing measure to capture economic development hence, the need to examine the effect of unemployment on economic development in Nigeria which is the objective of this paper.

The rest of the paper is divided into five sections. Immediately after the introduction in section one, is the conceptual clarification in section two. Section three is the method of study and technique of data analysis, while section four dwells on model specification. Section five is presentation of result and discussion of findings, while section six is conclusion and recommendations.

\section{CONCEPTUAL CLARIFICATION}

Summers (2002), define employment as a condition of not having a job, by an individual or the number of people who do not have a job.

Business Dictionary (2014), refers to unemployment rate as the percentage of total workforce who are unemployed and are looking for a paid job. Unemployment rate is one of the most closely watched statistics because a rising rate is seen as a sign of weakening economy that may call for cut in interest rate, A falling rate, similarly, indicates a growing economy which is usually accompanied by higher inflation rate and may call for increased interest rate.

Ahuja (2011), explained that, technically speaking, unemployment is defined as a state of affairs when in a country there are a large number of able-bodied persons of working age who are willing to work but cannot find work at the current wage levels. People who are either unfit for work for physical or mental reasons, or don't want to work e.g. Sadhus, are excluded from the category of the unemployed.

Interestingly Answers (2014), adds that, unemployment rate measures the percentage of employable persons in a country's work force who are over the age of 16 and who have either lost their jobs or have unsuccessfully sought for jobs in the last month and are still actively seeking for work. 
International Labour Organization (2003) defined unemployment as those who are those economically active populations who are without job but available for and seeking for job, including people who have lost their jobs and those who have voluntarily left work.

There are several forms of unemployment which include frictional; structural, cyclical and seasonal types of unemployment.

Frictional unemployment: This is the unemployment that results from the normal workings of the labour market, i.e. the fact that at any point in time, there will be people changing jobs. It is the unemployment suffered by people who are in the process of changing job. Thus, frictional unemployment is a temporary kind of unemployment.

Structural unemployment: This is the unemployment suffered by workers who have lost their jobs because of structural changes in the economy. An example is the case of people who have lost their jobs because of automation in the production processes. Another example is the case of people who have lost their jobs because the things their skills help to produce are no longer in demand. People who suffer this kind of unemployment often have to retain themselves for other kinds of jobs, if they must avoid prolonged periods of unemployment.

Cyclical unemployment: Cyclical unemployment as the name implies, results, from the fluctuation in economic activity, i.e. the cycles in business activities. It rises during recession, gets worse as a recession turns into a depression and fails during a boom (i.e. expansion).

Seasonal unemployment: This is the unemployment that occur owing to changes of the seasons of the year. It is mainly a feature of agrarian economies where economic activities are very much affected by the seasons. Because of these different types of unemployment, an economy, particularly, a market economy cannot be without some level of unemployment. This means that when economists talk of full employment, they do not mean a situation of zero unemployment.

\section{The Rising Unemployment Rate Profile in Nigeria}

Nigeria's unemployment rate increased to 23.9 percent in 2011 compared with 21.1 percent in 2010 and 19.7 percent in 2009, as revealed by the National Bureau of Statistics (NBS). The "Nigerian Unemployment Report (2011), prepared by the NBS shows that the rate is higher in the rural areas (25.6 percent) than in the urban areas (17.1 percent). The rise in the unemployment rate was largely attributed to the increased number of school graduates with no matching job opportunities, a freeze on employment in many public and private sector institutions as well as the slow disbursement of the capital budget by the Federal Government. The result of the survey by International Labour Organization (ILO) in Nigeria shows that persons aged 0 to 14 years constituted 39.6 percent, those aged between 15 and 64 (the economically active population) constituted 56.3 percent, while those aged 65 years and above constituted 4.2 percent.

Ironically, while the unemployment situation is worsening, the nation's economy is rated as one of the fastest growing economies in the world. The National Bureau of Statistics (NBS), puts the growth rate of the economy for 2013 at 6.75 percent, which Ngozi Okonjo-Iweala, Minister of Finance and Coordinating Minister of the Economy says its conservative given that the International Monetary Fund (IMF) rates it at 7.2 percent. Nigeria has the highest growth rate in Africa and one of the highest in the world. China's economy growing at 7.75 percent with a downward forecast of 0.25 percent for 2014, South Africa is growing at 3.3 percent; while IMF cut down the world economic growth which was 3.3 percent in April, 2013 to 3.1 
percent in July, 2013. This suggests that the Nigerian economy is growing at more than two times the global average (Osalor, 2014).

\section{Economic Development}

Todaro (1992) asserts that "development must therefore be conceived of as a multidimensional process involving changes in structures, attitudes and institutions as well as the acceleration of economic growth, the reduction of inequality and eradication of absolute poverty!! However for the purpose of this study, we shall adopt with little modification, the definition by Akpakpan (1987): according to him, Development can be defined qualitatively as a process of improvements in general welfare of the entire society. Usually manifested in desirable changes in the various aspects of the life of the society, such as:

- Reduction in the level of unemployment

- A reduction in absolute poverty

- A rise in real output of goods and services and improvement in production's techniques

- A reduction in the extent of personal and regional inequalities improvements in literacy, Health services, housing condition and government services,

- A reduction in the level of unemployment

- A reduction in pollution and/or environmental degradation (Wilson, 2000)

Development is more embracing than qualitative measures of considers equally the qualitative aspects of life of the people such as the reduction in the level of poverty, inequalities and unemployment etc. (Wilson 2002).

Akpakpan (1987) asserts that development must be a process by which the society achieves improvements in the various aspects of life usually manifested in greater job opportunities (reduction of unemployment), elimination of absolute poverty, reduction of socio-economic inequalities, improvement, in production techniques and greater self-reliance.

\section{The Classical Theory of Unemployment}

THEORETICAL LITERATURE

The classical theory of unemployment analyzed by Pigou (1933) and Solow (1981) state unemployment is product of market interference and labour demanding wage rate that is above the equilibrium rate. To solve the problem of unemployment the economy should be allowed to do the necessary adjustment on its own because it is self-regulatory.

\section{The Keynesian Theory of Unemployment}

To Keynes and his followers' unemployment exist in an economy as a result of deficiency in aggregate demand. Therefore, for the problem of unemployment to be solved there is need for government intervention in the economy.

\section{EMPIRICAL REVIEW}

Innocent (2014) in his study unemployment rate in Nigeria: Agenda for government stated that unemployment will always be present in an economy as industries expand and contract, as technological advances occur, as new generations enter the labour force, and as workers voluntarily search for better opportunities. This is why most economists agree that there is a natural rate of unemployment in the economy (usually 4\%-6\%). This natural rate is most affected by the number of youthful workers in the labour force, as well as public policies that discourages employment or job creation, such as a high minimum wage; generous unemployment benefits and few disincentives associated with lying off workers. 
Bhattarai (2016) examined the relationship between inflation and unemployment in 350ECD countries using a panel VAR model to analyse the quarterly data used from 1990:1 to 2014:4. He submitted that the Phillip's curve is still significant in 28 out 35 OECD countries and the coefficients of Okun curve for growth on unemployment were significant only in 13 of these countries. He concluded that as the natural rate of unemployment results from the balance between job creation and destruction processes, reductions in unemployment rates require complementing macro stimulations by microeconomic structural and institutional reforms. Sadiku, Ibraimi \& Sadiku (2015) empirically examined unemployment relation with growth in FYR Macedonia using VAR approach with a quarterly based data from 2000-2012. It was observed that no negative relationship between unemployment and economic growth as propounded by Okun's Law and also no direction of causality between unemployment and economic growth.

Abdul-Khaliq, Soufan, \& Shihab (2014) investigated the relationship between economic growth and unemployment rate in Arab countries between 1994 and 2010 adopting the Pooled EGLS (Cross-section SUR). It was found that economic growth had a negative and significant impact on unemployment rate, which implies that 1\% increase in economic Growth will decrease the unemployment rate by $0.16 \%$.

Amassoma and Nwosu (2013) examined the impact of unemployment on productivity growth in Nigeria using an error correction modeling approach and co-integration technique to analyse the data used from 1986 to 2010 . The regression estimate based on the short run and long run models showed that unemployment rate had an insignificant influence on productivity growth in Nigeria over the study period.

Ozei, Sezgin, and Topkaya (2013) investigated the relationship between economic growth and unemployment relationship in seven industrialized countries (G7) countries. Panel regression analysis was used to analyse data from 2000-2011. The results of the study revealed that while the productivity and economic growth variables have significant and strong effects on the reduction of unemployment in three-crisis period, this effect of productivity becomes insignificant and small after the crisis whereas the effect of economic growth as a decreasing effect over unemployment continues and its impact level rises.

Muhammad, Inuwa, and Oye (2011) examined the implication of unemployment on gross domestic product in Nigeria over the period of nine years (2000-2008) using a regression analysis. Findings showed that unemployment has an enormous effect (over 65\%) on the making of the Nigerian GDP and there exist an inverse relationship between unemployment and gross domestic product, which implies that as unemployment increases, gross domestic product falls.

Ejikeme (2014) assessed the link unemployment and poverty has on security in Nigeria. His study underscores that unemployment and poverty are universal phenomena, and not necessarily a peculiar characteristic of any particular segment of the society. The research revealed that unemployment and poverty have direct links to security challenges in Nigeria.

Holden and Sparman (2013) examined the effect of government purchases on unemployment in 20 OECD countries for the period 1980 to 2007. They observed that a one percent increase in government purchases of GDP reduced unemployment by about 0.3 percent in the same year. The effect was observed to be greater in downturns than in booms, and also under a fixed exchange rate regime than a floating regime. 
Akeju and Olanipekun (2014) validated the Okun's law in Nigeria using the Error Correction Method and Johansen cointegration technique. The findings showed that there is both a short and long run relationship between unemployment rate and output growth in Nigeria. Hence, there is need to incorporate fiscal measures and increase the attraction of foreign direct investment (FDI) to reduce the high rate of unemployment in the country.

Onwanchukwu (2015) examined the impact of unemployment on the economic growth in Nigeria from 1985 to 2010, using ordinary least squares regression technique. His findings revealed that unemployment does not have a significant impact on the economic growth of Nigeria. Inflation, however, was found to significantly impact on the economic growth of Nigeria.

Muhammad (2014) studied the effect of inflation and unemployment on the growth of Pakistan from 1980 to 2010 using the Auto regressive distributed lag. He firstly noted that inflation effect varies from economy to economy, but most of the studies indicate that there is a positive relationship between inflation and economic growth or GDP. The result showed that there is a long run relationship between the variables. Furthermore, the results of White's Heteroskedasticity, Ramsey reset and Breusch-GodfreySerial Correlation LM test shows that there is no problem of heteroskedasticity, misspecification of model and serial correlation respectively. It was recommended that self-employment/entrepreneurship should be encouraged to overcome the unemployment.

Madito and Khumalo (2014) examined unemployment nexus in South-Africa form 1971Q1 to 2013Q4 using the Error correction mechanism as a result of the dynamic inter-relationship between the variables used to check the speed of adjustment of economic growth to unemployment crisis. It was observed that about 62 percent of economic growth is corrected each quarter. The overall results showed that there is a negative relationship between economic growth and unemployment in South Africa.

Taylan (2012) investigated the relationship between macroeconomic variables and economic growth in Turkey from 2000Q1 to 2010Q2 using Vector Auto- Regressive Model (VAR). From his findings, it was revealed that positive shocks to growth, growth in export and inflation reduced unemployment. Also, shocks to exchange rate, interbank interest rate and money supply increased unemployment.

The conformity of the results is found to go in line with Phillips curve and Okun's Law suggestion namely, negative relationship between output and unemployment and positive relationship between unemployment and inflation.

Babalola, Saka and Adenuga (2013) validates Okun's law in Nigeria using a different approach of the VAR Cointegration to compare the two models (Shortrun and Long-run) from 19802012. It was observed that unemployment rate as an independent variable was positive and also positive for real GDP growth as an independent variable. These findings are contrary to Okun's law of unemployment-output relationship.

Ekrame, Dramane, and Christophe (2012) investigated the relationship between Immigration, Growth and Unemployment in 22 OECD countries using panel VAR technique to analyse data spanning from 1987 to 2009. Their result provided evidence that migration contributed to host economic prosperity (positive impact on GDP per capita and negative impact on aggregate unemployment, native and foreign-born unemployment rates). It was also found out that 
migration is influenced by host economic conditions (migration responds positively to host GDP per capita and negatively to host total unemployment rate).

Imran and Iba (2014) examine the relationship between macroeconomic variables and unemployment in Pakistan from 1980-2010 using the VAR Approach. From their findings, it was revealed that the variables have more variance contribution to themselves when compared to other variables in the system. Inflation rate contributed to unemployment variance more as compared to economic growth,

Unemployment contributes more to economic growth as compared to inflation and unemployment rate has also more variance contribution to inflation as compare to economic growth. In other words, unemployment rate has more variance contribution in both inflation and economic growth rate.

\section{RESEARCH METHODOLOGY}

The paper adopted econometrics technique of data analysis; the data for the study were collected Central Bank Statistical Bulletin and World Bank data bank. The data were subjected to unit root testing using the Augumented Dickey Fuller test. The Johansson cointegration test and the error correction mechanism were performed.

\section{Data set}

The following sets of data were used in the study

$\begin{array}{ll}\text { Unemployment rate } & \text { UMP } \\ \text { Human Development Index } & \text { HDI } \\ \text { Capacity utilization in manufacturing } & \text { CAU } \\ \text { Foreign direct investment } & \text { FDI } \\ \text { Government capital expenditure } & \text { GCE } \\ \text { Net export } & \text { NEX } \\ \text { Trade openness } & \text { TOP }\end{array}$

\section{Model Specification}

The researcher adopted the model of Mowan (2015) but with some modification. The mathematical form of the model is given as:

HDI = $\mathrm{f}($ UMP FDI GCE NEX TOP CAU ) which are as defined above. The econometrics form of the model is given below:

Where:

$$
\mathrm{HDI}=+\mathrm{b}_{0}+\mathrm{b}_{1} \mathrm{UMP}+\mathrm{b}_{2} \mathrm{FDI}+\mathrm{b}_{3} \mathrm{GCE}+\mathrm{b}_{4} \mathrm{NEX}+\mathrm{b}_{5} \mathrm{TOP}+\mathrm{b}_{6} \mathrm{CAU}+\mathrm{U}
$$


Model 1: Unit root test results

RESULTS, INTERPRETATION AND DISCUSSION

Unit Root Test

Table 4.1: Unit Root Test Result

\begin{tabular}{|l|l|c|l|c|c|c|}
\hline \multirow{2}{*}{ VARIABLE } & \multicolumn{2}{|c|}{ ADF } & Integration & \multicolumn{2}{|c|}{ PP } & Integration \\
\cline { 2 - 7 } & Level & $\begin{array}{c}\text { 1st } \\
\text { Difference }\end{array}$ & Order & Level & $\begin{array}{c}\text { 1st } \\
\text { Difference }\end{array}$ & Order \\
\hline HDI & 0.060789 & -4.345364 & $1(1)$ & 1.058695 & -5.23522 & $1(1)$ \\
UMP & 2.496025 & -9.333949 & $1(1)$ & 2.328147 & -10.22778 & $1(1)$ \\
FDI & 7.408514 & -5.840068 & $1(1)$ & 6.661769 & -3.313661 & $1(1)$ \\
GCE & 5.218843 & -8.572757 & $1(1)$ & 5.085769 & -3.709308 & $1(1)$ \\
NEX & 1.713110 & -7.305597 & $1(1)$ & 5.777956 & -7.254172 & $1(1)$ \\
TOP & 2.118110 & -8.111286 & $1(1)$ & 3.118236 & -7.182111 & $1(1)$ \\
CAU & 3.228661 & -7.002448 & $1(1)$ & 2.887661 & -6.263482 & $1(1)$ \\
\hline
\end{tabular}

Source: Author's computation, 2018.

ADF Critical value at level

$5 \%=-2.948404$

ADF at first difference

$5 \%=-2.948404$
Phillip-Perron critical value at level $5 \%=-2.929734$

At first difference

$5 \%=-2.931404$

NB: The unit root test is at $5 \%$ level of significance

The result of the unit root test in table 4.1shows that the variables are stationary at first difference, that is they are integrated of order one 1(1). This result justifies the use of Johansen cointegration to test for the existence of long run relationship. 


\section{The Johansen Cointegration Test}

Table 4.2: Johansen-Juselius Cointegration Test: Economic Development Model

Trend assumption: Linear deterministic trend

Series: HDI UMP FDI GCE NEX TOP CAU

Lags interval (in first differences): 1 to 3

Unrestricted Cointegration Rank Test (Trace)

\begin{tabular}{ccccc}
\hline \hline $\begin{array}{c}\text { Hypothesized } \\
\text { No. of CE(s) }\end{array}$ & Eigenvalue & $\begin{array}{c}\text { Trace } \\
\text { Statistic }\end{array}$ & $\begin{array}{c}0.05 \\
\text { Critical Value }\end{array}$ & Prob.** \\
\hline \hline None $^{*}$ & 0.972577 & 291.4950 & 95.75366 & 0.0000 \\
At most 1 & 0.787828 & 144.0437 & 69.81889 & 0.0000 \\
At most 2 & 0.535449 & 80.47894 & 47.85613 & 0.0000 \\
At most 3 & 0.437392 & 49.04488 & 29.79707 & 0.0001 \\
At most 4 & 0.419920 & 25.46279 & 15.49471 & 0.0012 \\
\hline \hline
\end{tabular}

Trace test indicates 4 cointegratingeqn(s) at the 0.05 level

* denotes rejection of the hypothesis at the 0.05 level

**MacKinnon-Haug-Michelis (1999) p-values"

"Unrestricted Cointegration Rank Test (Maximum Eigenvalue)

\begin{tabular}{ccccc}
\hline \hline $\begin{array}{c}\text { Hypothesized } \\
\text { No. of CE(s) }\end{array}$ & Eigenvalue & $\begin{array}{c}\text { Max-Eigen } \\
\text { Statistic }\end{array}$ & $\begin{array}{c}0.05 \\
\text { Critical Value }\end{array}$ & Prob. $^{* *}$ \\
\hline \hline None $^{*}$ & 0.972577 & 147.4513 & 40.07757 & 0.0001 \\
At most $1^{*}$ & 0.787828 & 63.56472 & 33.87687 & 0.0000 \\
At most 2 & 0.535449 & 31.43406 & 27.58434 & 0.0152 \\
At most 3 & 0.437392 & 23.58209 & 21.13162 & 0.0221 \\
At most 4 & 0.419920 & 22.32813 & 14.26460 & 0.0022 \\
\hline \hline
\end{tabular}

Max-eigenvalue test indicates 4 cointegratingeqn(s) at the 0.05 level

$*$ denotes rejection of the hypothesis at the 0.05 level

**MacKinnon-Haug-Michelis (1999) p-values"

Table 4.2 shows the result of the Johansen co-integration, both trace statistic and the maximin Eigenvalue statistic confirmed the existence of 4 cointegrating equation. This established that there is a long relationship among the variables, which necessitate the use of error correction mechanism to test the speed of adjustment. 


\section{The Parsimonious error correction mechanism Test}

\section{“Table 4.3Parsimonious Estimate for ECONOMIC DEVELOPMNT Model independent Variable: D(HDI)}

Sample (adjusted): 745

Included observations: 39 after adjustments

\begin{tabular}{|c|c|c|c|c|}
\hline Variable & Coefficient & Std. Error & t-Statistic & Prob. \\
\hline $\mathrm{C}$ & & & & \\
\hline $\mathrm{D}(\mathrm{GCE}(-2))$ & -0 & 0.384009 & & 0.0443 \\
\hline D(UMP $(-3))$ & .416063 & 0.429436 & 5.626 & 0.0000 \\
\hline $\mathrm{D}(\mathrm{FDI}(-2))$ & 2.236788 & 688 & -3.6 & 0.0010 \\
\hline $\mathrm{D}(\mathrm{NEX}(-1))$ & 0.847296 & 418 & & 0.0027 \\
\hline $\mathrm{D}(\mathrm{CIM}(-2))$ & 1.367245 & 421.5725 & 3.243202 & 0.0031 \\
\hline $\mathrm{D}(\mathrm{TOP}(-2))$ & 2.86 & 76 & & 0.2660 \\
\hline $\mathrm{D}(\mathrm{CAU}(-3))$ & 1.06 & & 38 & 0.0079 \\
\hline $\operatorname{ECM}(-1)$ & & & & 0.0000 \\
\hline -squarea & .705527 & \multirow{2}{*}{\multicolumn{2}{|c|}{ Mean dependent var }} & 34.36370 \\
\hline Adjusted R- & & & & \\
\hline squared & & \multicolumn{2}{|c|}{ S.D. dependent var } & 55.82308 \\
\hline S.E. of regression & 35.28979 & \multicolumn{2}{|c|}{ Akaike info criterion } & 10.19781 \\
\hline $\begin{array}{l}\text { Sum squared } \\
\text { resid }\end{array}$ & & \multirow{3}{*}{\multicolumn{2}{|c|}{$\begin{array}{l}\text { Schwarz criterion } \\
\text { Hannan-Quinn criter. } \\
\text { Durbin-Watson stat }\end{array}$}} & \\
\hline Log likelihood & -187.8573 & & & 10.36616 \\
\hline F-statistic & 6.708523 & & & 2.474566 \\
\hline Prob(F-statistic) & $0.000031^{\prime \prime}$ & & & \\
\hline
\end{tabular}

Source: Author's computation, using E-views 9.0

Table 4.3 shows that the explanatory variables explain 60 percent of the variation in the explained variable (HDI), the remaining 40 percent is explained by variables not capture in the model. The Durbin-Watson Statistics of 2.47 shows the absence of autocorrelation. The FStatistic probability value of 0.000031 shows that the model is well specified. The ECM value 0.4323 has the appropriate sign but shows a slow adjustment process of about 43 percent.

The parsimonious result shown in table 4.3, shows that unemployment has a negative coefficient and it is statistically significant. A percentage increase in unemployment at period 3 contributes about -2.41 percent reduction in economic development proxy by human development index (HDI).This implies that an inverse relationship exist between unemployment and economic development. Foreign direct investment (FDI) at lag period 2 has a direct relationship with economic development. Government expenditure on capital project (GCE) at period 2 has a negative coefficient and it is statistically significant. This implies that an inverse relationship exists between GCE and economic development. One percent increase in GCE will reduce economic development by 0.37 percent.

Net export (NEX) at period 2 has a positive coefficient and it is statistically significant. A percentage increase NEX resulted in about 0.85 percent increase in economic development. 
Trade openness (TOP) at period 3 has a negative coefficient and it is statistically significant. Capacity utilization (CAU) has a positive coefficient and it is statistically significant and conforms to theoretical expectation. The implication is that a direct relationship exists between CAU and economic development in Nigeria.

\section{CONCLUSION}

From the result of the data analyzed, the researcher conclude that an inverse relationship exist between unemployment and economic development in Nigeria. This implies the higher the rate of unemployment the lower the rate of economic development. This shows unemployment is a cog the wheel of our development. This because the human development index the proxy for economic development is negatively affected by unemployment.

\section{RECOMMENDATIONS}

- Government should stimulate all the sectors of the economy as this will propel the expansion of the sectors hence creating employment opportunities to absorb our teeming unemployed youths.

- The government should promote industrialization by establishing a pilot industry.

- Skill acquisition and on the job train should be introduced and religiously implemented.

- Entrepreneurial education should be entrenched in our school curriculum both at the secondary and tertiary institutions, as to make our youth employer of labour.

- Finally, interest rate should be reviewed downward to enable our local investors borrow for production purposes.

\section{References}

Ahuja, H.L. (2011). Macroeconomics: Theory and Policy Based Mainly on UGC Model Curriculum. S. Chand and Company, Delhi, India.

Akeju, K. F. and Olanifekun, D.B. (2014). Unemployment and economic growth in Nigeria. Journal of Economics and Sustainable Development, Vol. 5, No.4

Akpakpan, E. B. (1999). The Economy: Towards a New Type of Economics, Belpot Nigeria Go, Port Harcourt.

Alanana, 0. (2003). Youth unemployment in Nigeria, some implications for the third millennium. Global Journal of Social Sciences 2(1): 21-26.

Darby, M.R. (1970). Macro economics: The Theory of Income, Employment and the Price Level. McGraw Hill Book Company. California.

Ezie, O. (2012). Youth unemployment and its socio-economic implications in Nigeria. Journal of Social Science and Public Policy. 4: 112-119. ISSN 2277-0038

George, E. $O$ and Oseni, J. $O$ (2012). The relationship between electricity power and unemployment rates in Nigeria. Australian Journal of Business and Management Research. 2(02): 10-1.

Imran. A. \& Iba. S. (2014). Examining relationship between macroeconomic variables using VAR Approach. Proceedings of the 2014 International Conference on Industrial Engineering and Operations Management. Bali, Indonesia, January 7 - 9.

Innocent, E.O. (2014). Unemployment rate in Nigeria: Agenda for government. Academic Journal of Interdisciplinary studies, MCSER, Publishing, Rome- Italy.

International Labour Organization (2014). Global Employment Trends. Geneva: ILO.

Johanson, S. and Juselius, K. (1990). Maximum likelihood estimation and inference on cointegration with applications to the demand for money. Oxford Bulletin of Economics and Statistics, 52:169-210.

Li, C. \& Liu, Z.J. (2012). Study on the relationship among Chinese unemployment rate, economic growth and inflation. Advances in Applied Economics and Finance, 1(1), pp. 1-6.

Madito, O. \& Khumalo, J. (2014). Economic growth - unemployment nexus in South Africa: VECM Approach. Mediterranean Journal of Social Sciences. 5(20), pp. 79-84. 
Muhammad, S. (2014). Effect of inflation and unemployment on economic growth in Pakistan. Journal of Economics and Sustainable Development. 5(15), pp. 103-106.

Muhammad, S. A.; Oye, N.D. \& Inuwa I. (2011). Unemployment in Nigeria: implication on the gross domestic product (gdp) over the years. Int. J. ECO. RES, 2(1), pp. 66-71.

National Bureau of Statistics (2012). The Nigeria Poverty Profile, Abuja: NBS.

National Bureau of Statistics. (2017). National Unemployment Rates (1995 - 2011). Retrieved from: www.nigerianstat.gov.ng on 9th November, 2017.

Ndubisi, E. C. and Nwankwo, C.A. (2013). Tackling unemployment through private sector. International Journal of Innovation Research in Management. 2(2): 41-52. ISSN 2319-6912.

Njoku, A. and O. Ihugba, (2011). Unemployment and Nigerian economic growth (1985-2009). Proceeding of the 2011 International Conference on Teaching, Learning and Change. International association for teaching and learning (IATEL).

Okun, A. M. (1962). Potential GNP: Its measurement and significance, American Statistical Association, Proceedings of the Business and Economics Statistics Section, pp. 98-104.

Onwanchukwu, C. I. (2015). Does unemployment significantly impact on economic growth in Nigeria? Global Journal of Human-Social Science: E Economics, 15(8), pp. 23-26.

Osalor, P. (2014). Breaking the Nigerian poverty cycle through entrepreneurial revolution Part 1, Vanguard, Monday, March, 31, p.18.

Osinubi. (2006). The political crisis \& solution Vanguard July 19.

Ozei, H. A.; Sezgin, F.H. \& Topkaya, O. (2013). Investigation of economic growth and unemployment relationship for G7 Countries using panel regression analysis. International Journal of Business and Social Science.4(6), pp. 163-171.

Papapetrou, E. (2001). Oil price shocks, stock market, economic activity and employment in Greece. Energy Economics, 23(5), pp. 511-532.

Phillips, A.W. (1958). The relationship between unemployment and the rate of change of money wages in the United Kingdom 1861-1957. Economica, 25(100), pp. 283-299.

Sadiku, M.; Ibraimi, A. \& Sadiku, L. (2015). Econometric Estimation of the Relationship between Unemployment Rate and Economic Growth of FYR of Macedonia. Procedia Economics and Finance, pp. 19, 69 - 81.

Summers, D. et al., (2002). Longman Dictionary of American English (NE). Pearson Education, England.

Taylan, T. D. (2012). Macroeconomic variables and unemployment: the case of Turkey. International Journal of Economics and Financial Issues, 2(1), pp. 71-78.

Udabah, S. I. (1999). Basic Economics Theory and Practice. Enugu, Linco Press Nigeria Limited.

US, The Bureau of Labour Statistics Reports (2014). Employment Situation Report, Washington DC: Bureau of Labour Statistics.

Yahaya, Y., Salisu, B. M. \& Umar, B. (2015). Electricity supply and manufacturing output in Nigeria: Autoregressive Distributed Lag (ARDL) Bound Testing Approach. Journal of Economics and Sustainable Development, 6(17), pp. 7-19. 